\title{
The Establishment of \\ Hop Tissue Cultures and their Infection by Downy Mildew Pseudoperonospora humuli (Miy. \& Tak.) Wilson under Aseptic Conditions
}

\author{
By M. J. GRIFFIN AND J. R. COLEY-SMITH \\ Department of Botany, The University of Hull \\ (Accepted for publication 5 April I968) \\ SUMMARY
}

\begin{abstract}
Successful infection of hop tissue culture with Pseudoperonospora humuli was achieved. Infection was obtained from hyphae emerging from surfacesterilized systemically infected stems and petioles. Externally, infection was characterized by sterile aerial hyphae and sporangiophores, and internally by intercellular mycelium and intracellular haustoria. Although a considerable growth of mycelium into the agar medium was observed, it appeared to be dependent on the presence of host tissue. Attempts to establish axenic cultures of $P$. humuli were unsuccessful.
\end{abstract}

\section{INTRODUCTION}

Pseudoperonospora humuli is a member of the family Peronosporaceae and, as far as we are aware, has not previously been grown under aseptic conditions. All members of this family are obligate parasites and a few species have been grown on tissue cultures of their respective hosts. The growth of an obligate parasite in tissue culture was first achieved by Morel (1944, 1948) with vine downy mildew Plasmopara viticola. Since then at least two other downy mildews, Peronospora parasitica (Nakamura, I965) and Peronospora tabacina (Izard, Lacharpagne \& Schiltz, 1964) have been grown in tissue culture. A few rusts and powdery mildews, the other two main groups of obligate parasites, have also been grown in tissue culture (Brian, r967). The present paper describes the establishment of hop tissue culture and its infection with $P$. humuli under aseptic conditions.

\section{METHODS AND OBSERVATIONS}

Tissue culture medium. Tissue cultures of Humulus lupulus (L.) var. Eastwell Golding were initiated and maintained on a solid medium based on Hildebrandt (1962) D-medium. The composition of the medium was: mineral salts: $\mathrm{Na}_{2} \mathrm{SO}_{4}, 800 \mathrm{mg}$; $\mathrm{Ca}\left(\mathrm{NO}_{3}\right)_{2} \cdot 4 \mathrm{H}_{2} \mathrm{O}, 400 \mathrm{mg}$; $\mathrm{MgSO}_{4} \cdot 7 \mathrm{H}_{2} \mathrm{O}, 180 \mathrm{mg}$.; $\mathrm{KNO}_{3}, 80 \mathrm{mg}$; $\mathrm{KCl}, 65 \mathrm{mg}$.; $\mathrm{Na}_{2} \mathrm{HPO}_{4} \cdot \mathrm{I}_{2} \mathrm{H}_{2} \mathrm{O}, 33 \mathrm{mg}$. trace elements: $\mathrm{ZnSO}_{4} \cdot 7 \mathrm{H}_{2} \mathrm{O}, 6 \cdot 0 \mathrm{mg}$; $\mathrm{MnSO}_{4} \cdot 4 \mathrm{H}_{2} \mathrm{O}$, $4.5 \mathrm{mg}$.; KI, $3.0 \mathrm{mg}$.; $\mathrm{H}_{3} \mathrm{BO}_{3}, 0.3 \mathrm{mg}$; other additions: EDTA (Na/Fe complex; $\mathrm{Na}_{2} \mathrm{EDTA}, 0.0372 \mathrm{~g}$. $+\mathrm{FeSO}_{4} \cdot 7 \mathrm{H}_{2} \mathrm{O}$, 0.0278 g.) $65 \mathrm{mg}$.; glycine, $3.0 \mathrm{mg}$.; thiamine, $0.1 \mathrm{mg}$; calcium pantothenate, $2.5 \mathrm{mg}$.; nicotinic acid, $0.5 \mathrm{mg}$.; pyridoxine, $0.8 \mathrm{mg}$.; $\alpha$-naphthylacetic acid, $0.1 \mathrm{mg}$; 2,4-dichlorophenoxyacetic acid, $6.0 \mathrm{mg}$.; sucrose, 20 g.; Difco yeast extract, I g.; coconut milk, $260 \mathrm{ml}$. The medium was made up to 
I 1. with distilled water and solidified with $0.6 \%(\mathrm{w} / \mathrm{v})$ Davis agar. Sterilization was by autoclaving for $\mathrm{I} 5 \mathrm{~min}$. at $\mathrm{I} 2 \mathrm{I}^{\circ}$.

Initiation of hop callus. Callus tissue was initiated from lengths of stem internode of Eastwell Golding. Lengths ( $3 \mathrm{~cm}$.) of stem were dipped in $95 \%(\mathrm{v} / \mathrm{v})$ ethanol in water for 30 sec., surface-sterilized in a saturated solution of calcium hypochlorite for $7 \mathrm{~min}$. and finally washed 3 times with sterile distilled water. The ends of the stem were then cut off aseptically and a $\mathrm{I}$ to $\mathrm{x} \cdot 5 \mathrm{~cm}$. length placed on $20 \mathrm{ml}$. of the agar medium in a plastic Petri dish and incubated in the dark at $25^{\circ}$. Explants which showed no signs of bacterial contamination after one week ( 30 to $40 \%$ of total) were transferred to Pyrex boiling tubes containing $10 \mathrm{ml}$. agar medium (see Pl. I, fig. I to 3 ). Tightly fitting cottonwool plugs and aluminium foil caps decreased evaporation during the lengthy incubation period. Latent bacterial contamination occasionally appeared from some explants even after 4 weeks of incubation. Prolonging the immersion in calcium hypochlorite to Io min. decreased the number of explants which were contaminated, but in most cases prevented callus formation.

\section{Characteristics of callus growth}

Callus formation was normally visible after $\mathrm{I}$ to 3 weeks and was followed by vigorous growth of white callus (Pl. I, fig. I). Several of the explants also produced adventitious roots and others died without forming a callus. In most cases the initial growth of white callus was normally followed by dehydration and eventual death over a period of 6 to 8 weeks. Callus death was not prevented by transferring the explant to fresh medium.

A few explants, however, produced sectors of brown callus amongst the original white callus (Pl. I, fig. 2). The thicker woody explants from the base of the stem produced these brown sectors more readily. Growth of this brown tissue was very slow and no attempt was made to separate it from the original explant for 12 to 15 weeks. After separation, the sectors became darker brown and grew very slowly for 15 to 20 weeks. Lightish brown sectors of callus were then produced, with an improved growth rate. These sectors were selected out and placed on fresh medium and the improved growth rate has been maintained. Fifty boiling tubes of callus on solid medium (Pl. I, fig. 3) were kept as a stock and subcultured every 8 weeks. No attempts to infect callus with Pseudoperonospora humuli were made until a stock of 50 callus cultures had been built up. Slight changes in the colour and in the rate of growth of the callus have occurred frequently.

\section{Aseptic isolation of Pseudoperonospora humuli}

The organism was isolated from systemically infected shoots of Eastwell Golding. Material was obtained from naturally-infected field plants and from artificially infected shoots. The latter can be produced by spraying young shoots ( 2 to $7 \mathrm{~cm}$. high) emerging from a hop rootstock, with a sporangial or zoospore suspension of $P$. humuli, incubating in a polythene bag at $14^{\circ}$ for $12 \mathrm{hr}$, then allowing the shoots to dry and grow in the normal manner.

The stems and petioles of systemically infected shoots were cut into $2 \mathrm{~cm}$. lengths, dipped in $95 \%(\mathrm{v} / \mathrm{v})$ ethanol in water for $30 \mathrm{sec}$., surface-sterilized in calcium hypochlorite for Io min. and then washed 6 times with sterile distilled water. The sections of stem and petiole were then placed on $15 \mathrm{ml}$. of solid medium in plastic Petri dishes 
and incubated at $25^{\circ}$. The incidence of bacterial contamination of surface-sterilized sections was usually less than $50 \%$.

After 3 days, many of the petiole sections and a smaller proportion of stem sections were covered with sporangiophores bearing sporangia. Sterile hyphae were also produced, some aerial (Pl. I, fig. 4) and some growing into the agar adjacent to the infected material. Removal of infected stems and petioles, after 7 days, revealed a considerable growth of mycelium of $P$. humuli in the agar (Pl. I, fig. 5). However, no further mycelial growth occurred after removal of the host tissue.

\section{Infection of tissue cultures}

Infection of hop callus with Pseudoperonospora humuli was achieved by placing lengths of stem and petiole (sterilized 7 days previously) bearing sporangia and aerial hyphae on $\mathrm{I}$ o $\mathrm{ml}$. of the solid medium in boiling tubes. These were then surrounded or covered with hop callus tissue and incubated in a growth room at 14 to $15^{\circ}$, with a I $6 \mathrm{hr}$ photoperiod at 300 lux. After I week hyphae from infected stems and petioles were seen growing into the adjacent callus. The growth was very slow and, after 3 weeks, infection was only observed on callus adjacent to the infected material. The time taken for infection to spread over all or a high proportion of the uninfected callus varied from 6 to 20 weeks. External characteristics of infection were sterile aerial and surface hyphae, and sporangiophores bearing sporangia ( $\mathrm{Pl}$. 2, fig. 6, 7). The hyphae and sporangiophores varied markedly in density even over small areas of callus. The aerial and surface hyphae often had an irregular shape and branching habit, a feature characteristic of $P$. humuli in natural conditions (Coley-Smith, 1964). A considerable growth of mycelium was again observed in the agar medium, adjacent to the infected material. Hyphae emerged both from infected callus, and from infected stems and petioles, but rarely advanced more than $\mathrm{I} \mathrm{cm}$. into the agar. There was a marked decrease in density of mycelium with increase in distance from infected material. No fruiting structures were seen on the hyphae in the agar.

After Io to 20 weeks callus on which Pseudoperonospora humuli had become established was removed from the boiling tube, subdivided in a sterile Petri dish and small infected sectors placed on $10 \mathrm{ml}$. of fresh agar. These were then covered with uninfected callus, on which infection usually became established within a week. Again, the rate of spread of infection varied markedly in different cultures. In this way $P$. humuli has so far been perpetuated in hop tissue for 7 months.

The presence of infected material in close proximity to uninfected callus did not appear to retard the growth rate of the latter. When sectors became heavily infected, however, growth appeared to cease. Attempts have been made to infect callus with sporangial and zoospore suspensions, obtained by washing sporangia from surfacesterilized systemically infected stems and petioles with sterile distilled water. So far infection has not been obtained.

\section{Mycelium of Pseudoperonospora humuli in the agar}

Attempts were made to grow $P$. humuli in axenic culture. Infected tissue cultures which supported a dense growth of mycelium into the agar were selected. The infected callus was carefully removed from the boiling tube, leaving some mycelium in the agar; but in the absence of host tissue no further mycelial growth took place. In another experiment small pieces of agar $(0.5$ to $\mathrm{I} \cdot 0 \mathrm{~cm}$. across) which contained myce- 
lium were placed on fresh agar, and half of these were covered with uninfected callus. No further mycelial growth or infection of callus occurred.

\section{Cytological investigation}

Small sections of callus heavily infected with Pseudoperonospora humuli were selected for cytological examination. Material for permanent sections was fixed in formalin + acetic acid + ethanol (Johansen, I940), dehydrated in ethanol amd embedded in fibrowax. Sections (Io $\mu$ thick) were stained with I \% aqueous resorcin blue and dehydrated rapidly in absolute ethanol. Resorcin blue is a specific stain for callose which is deposited around haustoria and hyphae by host cells (Fraymouth, 1956).

Microscopical observation of stained sections showed that systemic infection was characterized by intercellular mycelium and intracellular haustoria. Haustoria and cell walls adjacent to intercellular mycelium were stained pale blue. The haustoria varied considerably in form but were usually branched or knob-like (Pl. 2, fig. 8). These observations were confirmed by squashing small pieces of fresh material and staining with resorcin blue. The haustoria were stained a much deeper blue in fresh material. Also small haustoria-like projections, which stained deeply, were seen at irregular intervals on some of the hyphae. No penetration of cells by such haustoria was observed. A similar phenomenon was observed with Phytophthora infestans on tissue aggregates of Solanum tuberosum (Ingram, 1967). No deeply staining structures were seen when uninfected callus was squashed and stained in the same way. The characteristics of haustoria and mycelium of $P$. humuli in hop tissue culture compare closely with those observed in naturally infected hop rootstocks (Coley-Smith, I964).

\section{DISCUSSION}

The general pattern of growth of Pseudoperonospora humuli on hop tissue culture was similar to that described for Plasmopara viticola (Morel, 1944, 1948) and Peronospora tabacina (Izard, et al. 1964). However, with these two organisms no growth of hyphae from the infected callus into the agar medium was reported. Stow \& Ihara (I962) claimed to have observed the emergence of mycelia of $P$. humuli from infected leaf tissue on to a modified White's medium, with consequent oospore production. In the present work no oospore production was observed. Cutter (1951, 1959, 1960) established axenic cultures of Gymnosporangium juniper-virginianae and Uromyces ari-triphylli on nutrient agar. From a small proportion of infected tissue cultures, hyphae grew into the agar and were then removed and grown in isolation on fresh agar. These axenic cultures retained their ability to parasitize host tissue. With $P$. humuli the case was very different. Hyphae always grew into the agar from adjacent infected tissue but when the host was removed their growth ceased and their ability to infect host material was lost.

It appeared that the growth into the agar of mycelium of Pseudoperonospora humuli was host-dependent; the host metabolites which must be responsible for this phenomenon are at present not known. The fact that there was no stimulatory effect of the solid or liquid medium on germ-tube growth provided further evidence for this dependence on host materials. The unknown growth principles are presumably translocated in the hyphae to the growing tip. If the hyphae are unable to translocate these over large distances, this might explain why growth in the agar is limited to I $\mathrm{cm}$. and why 
there is a marked decrease in density of mycelium with increasing distance from the infected host.

This work was initially done to investigate the possibility of producing sporangia aseptically in sufficient quantities for experiments involving the uptake of certain fungicides. However, the slow growth rate of the callus and the slow spread of infection have excluded this possibility. Surface-sterilized systemically infected stems and petioles offer more promising possibilities in this field.

Our thanks are due to Mr P. E. Smith for assistance with the photography and to the Science Research Council for the support of one of us (M.J.G.).

\section{REFERENCES}

BRIAN, P. W. (1967). Obligate parasitism in fungi. Proc. R. Soc. B I68, Ior.

Coley-Smith, J. R. (1964). Persistence and identification of downy mildew Pseudoperonospora humuli (Miy. \& Tak.) Wilson in hop rootstocks. Ann. appl. Biol. 53, $\mathrm{I} 29$.

CUTTER, V. M. (195I). The isolation of plant rusts upon artificial media and some speculations on the metabolism of obligate plant parasites. Trans. N.Y. Acad. Sci. 14, I03.

CUTTER, V. M. (1959). Studies on the isolation and growth of plant rusts in host tissue cultures and upon synthetic media. I. Gymnosporangium. Mycologia 5I, 248.

CuTter, V. M. (1960). Studies on the isolation and growth of plant rusts in host tissue cultures and upon synthetic media. II. Uromyces ari-triphylli. Mycologia 52, 726.

Fraymouth, J. (I956). Haustoria of the Peronosporales. Trans. Br. mycol. Soc. 39, 79.

HiLdebrandT, A. C. (1962). Tissue and single cell cultures of higher plants as a basic experimental method. In Moderne Methoden der Pflanzenanalyse. Ed. by M. V. Tracey and H. F. Linskens. Vol. 5, p. 383. Berlin: Springer-Verlag.

INGRAM, D. S. (1967). The expression of R-gene resistance to Phytophthora infestans in tissue cultures of Solanum tuberosum. J. gen. Microbiol. 49, 99.

Izard, C., Lacharpagne, J. \& Schiltz, P. (I964). Behaviour of Peronospora tabacina in tissue cultures, and role of the leaf epidermis. Annls Div. Etud. Equip. SEITA, I (Sect. 2), p. 95.

Johansen, A. J. (1940). Plant Microtechnique. New York: McGraw Hill Co. Inc.

Morel, G. (1944). Le développement du mildiou sur des tissus de vigne cultivés in vitro. $C$. $r$. hebd. Séanc. Acad. Sci., Paris 218, 50.

MoReL, G. (1948). Recherches sur la culture associée de parasites obligatoires et de tissus végétaux. Annls Épiphyt. $\mathbf{4}$ (N.S.), r.

Nakamura, H. (1965). The use of tissue cultures in the study of obligate parasites. In Proc. int. Conf. Plant Tissue Culture, p. 535, Berkeley, California: McCutchan Publ. Co.

STOw, I. \& IHARA, K. (1962). A note on the preliminary investigation of the artificial culture of hop downy mildew fungus, Pseudoperonospora humuli (Miy. et Tak.) Wilson. Bull. Brew. Sci. 7, 37.

\section{EXPLANATION OF PLATES}

Plate I

Fig. I to 3. Stages in the initiation of tissue cultures of Humulus lupulus from lengths of stem internode. Grown on $10 \mathrm{ml}$. of solid medium in $6 \times 1$ in. Pyrex boiling tubes.

Fig. I. White callus formation on stem explant. 30 days.

Fig. 2. Brown sectors amongst the white callus, on woody explant from the base of the plant. Io weeks.

Fig. 3. Actively growing stock tissue culture completely separated from original explant.

Fig. 4, 5. Growth of Pseudoperonospora humuli from lengths of surface sterilized systemically infected stem and petiole, placed on solid medium and incubated at $25^{\circ}$.

Fig. 4. Sporangiophores and sterile aerial hyphae. 5 days.

Fig. 5. Mycelium which had grown into the agar from a systemically infected stem. 7 days. 
Plate 2

Fig. 6 to 8. Growth of Pseudoperonospora humuli on tissue cultures of Humulus lupulus.

Fig. 6, 7. Sporangiophores bearing sporangia; and sterile aerial hyphae.

Fig. 8. Intracellular haustoria in section (10 $\mu$ thick) of hop callus. Stained with resorcin blue. 
Journal of General Microbiology, Vol. 53, No. 2

Plate I
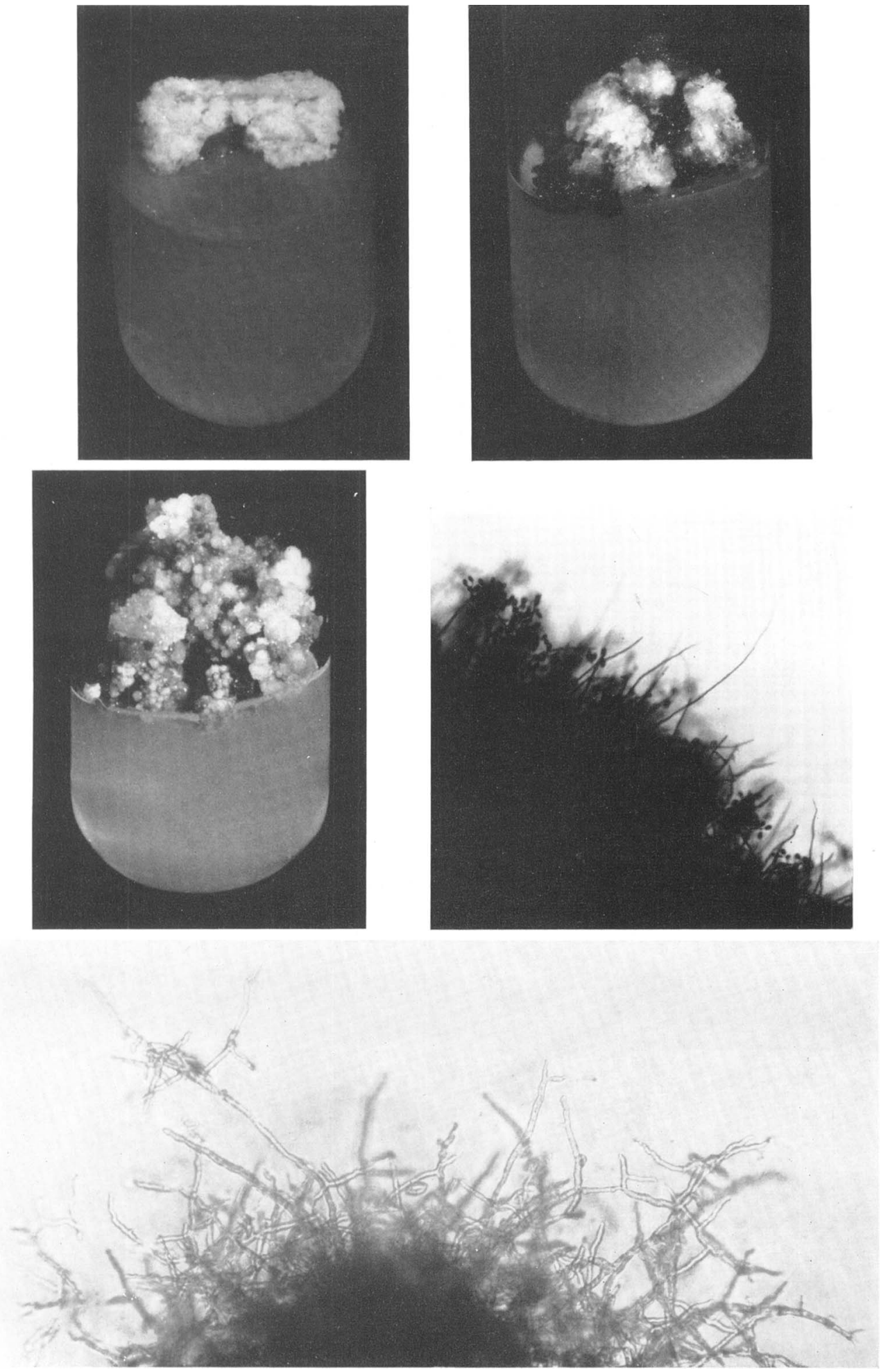

M. J. GRIFFIN ANI) J. R. COLEY-SMITH

(Facing p. 236) 

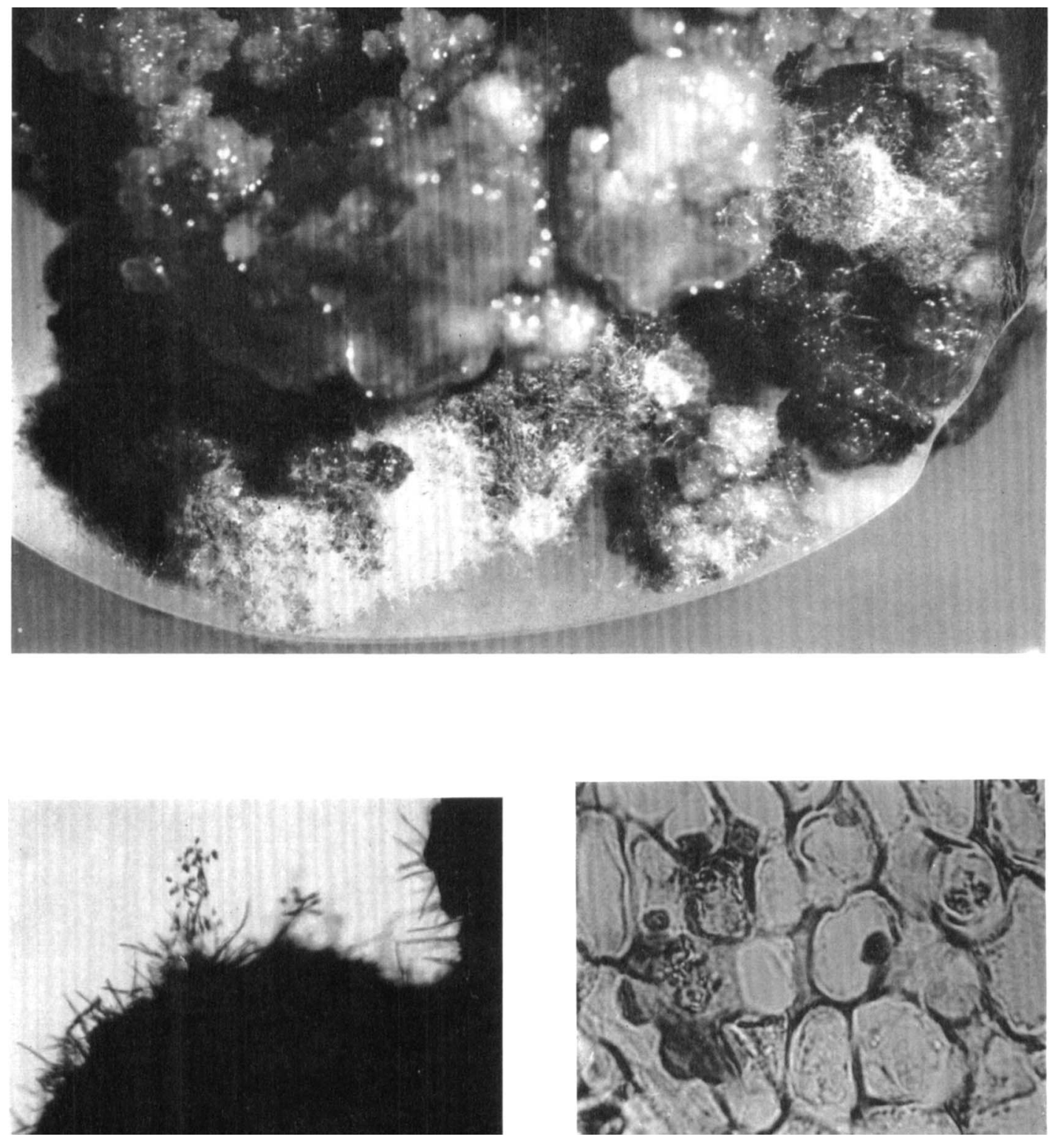